Mary A. Starsnic MD, Michacl E. Goldberg MD, Deborah E. Ritter mD, Alexander T. Marr CRNA, Mitchel Sosis MD PHD, Ghassem E. Larijani, PHARM D

\section{Does vecuronium accumulate in the renal transplant patient?}

atracurium ( $57.99 \pm 8.22$ mins) in those patients who reached 90 per cent $T$, recovery before the end of the surgical procedure. Also a comparison of REC $9 \mathrm{O}_{2}$ and REC 90, (Diff 90) for atracurium and vecuronium, respectively, showed $R E C \mathrm{OO}_{2}$ to be significantly longer for each group in these patients who received two doses of relaxant. However, an examination of the raw data reveals the Diff 90 of vecuronium $(25.62 \pm 4.34$ mins) to be much longer than for atracurium ( $13.77 \pm 3.35$ mins) even though equipotent doses of the drugs were administered. Therefore, there is evidance that vecuronium may accumulate in the cadaver renal transplant patient. injection to 90 per cent $T_{1}$ (REC 90,) and time from 25-75 per cent recovery $T_{1}$ (REC 25-75,). Maximum blockade (Max block ${ }_{1}$ ) was also measured. At 90 per cent $T_{1}$ recovery, if time permitted, an identical dose of the appropriate relaxant was administered. Time from second dose to onset of maximum block (second dose Max) and 90 per cent recovery after second dose $\left(\mathrm{REC} 9 \mathrm{O}_{2}\right)$ were then measured. At the conclusion of surgery, nearomuscular blockade was reversed with neostigmine $2.5 \mathrm{mg}$ and glycopyrrolate $0.5 \mathrm{mg}$. One way ANOVA was performed to determine significance between the groups and a $p<0.05$ was considered significant. A paired t test was also performed between REC 90 and $\mathrm{REC} 9 \mathrm{O}_{2}$ for atracurium and vecuronium respectively. A $p<0.05$ was again considered significant. Measurement of first dose Max, start REC , REC 25, REC 75, REC 90, REC 25-75, and Max block, revealed no difference between the patients receiving an initial dose of atracurium and those receiving vecuronium. In those palients receiving a second dose of relaxant there was no difference in onset of maximum block (second dose Max). However, time to 90 per cent recovery $\left(\mathrm{Rec} 9 \mathrm{O}_{2}\right.$ ) after a second dose of vecuronium (89.23 \pm 25.97 mins) was significantly longer than after a second dose of

\section{Key words}

NEUROMUSCULAR RELAXANTS: atricurium, vecuronium; PHARMACOKINETICS: drug accumulation; RENAL TRANSPLANTATION: angesthesia.

From the Thomas Jefferson University Hospital, Department of Anesthesiology, 10th \& Walnut Streets - 414 Main, Phila delphia, Pennsylvania 19107.

Address correspondence to: M.A. Starsnic.

Presented in part at the annual meeting of the International Research Society, Orlando, Florida, March 1987.
Hunter et al. ${ }^{1}$ compared vecuronium and atracurium in patients with normal and absent renal function undergoing a variety of surgical procedures. They found no difference between the two groups in duration of action of either drug and no evidence of accumulation. Fahey et $a l^{2}{ }^{2}$ compared the pharmacokinetics of vecuronium in patients with and without renal failure and found no significant difference in duration or evidence of accumulation between the two groups. Other authors ${ }^{3,4}$ have demonstrated that atracurium showed no evidence of accumulation or prolongation of effect in the renal failure patient. However, some studies have shown prolongation of effect ${ }^{5}$ and evidence of cumulation ${ }^{6}$ with vecuronium in the anephric patient.

Since vecuronium is a non-depolarizing relaxant which produces a neuromuscular blockade of short duration and without adverse cardiovascular effects, ${ }^{2}$ it would seem ideal for the renal transplant patient. These patients frequently have accompanying multiple organ system disease and the procedure is one during which hypotension can have markedly adverse effects. While the muscle relaxant properties of atracurium and its lack of dependence on renal clearance for elimination make it seem useful for the transplant population, its possible histamine release with concomitant hypotension ${ }^{7}$ could limit its use in this group. The purpose of this study is to compare the neuromuscular effects of atracurium and vecuronium in the cadaver renal transplant patient.

\section{Methods}

After Institutional Review Board approval and informed consent, 20 ASA physical status Class III patients 
undergoing cadaveric renal transplantation were studied. All patients were free of uraemic neuropathy and assigned by computer generated randomization to receive either atracurium or vecuronium. Premedication consisted of morphine sulphate $0.08 \mathrm{mg} \cdot \mathrm{kg}^{-1}$ and glycopyrrolate $0.01 \mathrm{mg} \cdot \mathrm{kg}^{-1}$ up to $0.3 \mathrm{mg}$ IM one hour before surgery. Induction consisted of thiopentone $4-6 \mathrm{mg} \cdot \mathrm{kg}^{-1}$ IV followed by succinylcholine $1.0 \mathrm{mg} \cdot \mathrm{kg}^{-1}$ to facilitate tracheal intubation. Maintenance of anaesthesia consisted of isoflurane (ET concentration of $0.5-1.0$ per cent as determined by a Beckman LB-3 end tidal monitor) in 50 per cent $\mathrm{N}_{2} \mathrm{O} / 50$ per cent $\mathrm{O}_{2}$ and fentanyl 4-6 $\mu \mathrm{g} \cdot \mathbf{k g}^{-1}$ IV.

After induction and prior to succinylcholine administration, the ulnar nerve was stimulated with supramaximal $2 \mathrm{~Hz}$ train-of-four square wave impulses $(0.2 \mathrm{msec}$ duration) every 10 seconds via 25 -gauge subcutaneous elecrodes placed at the wrist. Supramaximal stimulus was confirmed by increasing the voltage of the nerve stimulator until no further increase of the twitch height was observed. Subsequently, the voltage was increased to 20 per cent above this value which was accepted as supramaximal. Neuromuscular function was measured continuously by recording the force of thumb adduction with a Grass polygraph (Model 7) via a Grass FT10 force transducer (Grass Medical Instruments, Quincy, Mass. U.S.A.).

After a baseline TOF was obtained, succinylcholine was administered. Time to maximum block was recorded (SDC Max). After 90 per cent recovery of $T_{1}$ from succinylcholine (SDC Rec 90) either atracurium (ATR) $0.25 \mathrm{mg} \cdot \mathrm{kg}^{-1}$ or vecuronium (VEC) $0.05 \mathrm{mg} \cdot \mathrm{kg}^{-1}$ were administered and the following times were noted: time to maximum block onset (first dose Max), injection to start of recovery (Start $R E C_{1}$ ), injection to 25 per cent $\mathrm{T}_{1}$ twitch recovery $\left(\mathrm{REC} 25_{1}\right)$, injection to 75 per cent twitch recovery (REC 75 $)$, injection to 90 per cent twitch recovery (REC 901) and time from 25-75 per cent recovery (REC 25-75 ). Maximum blockade percentage (MAX block $_{1}$ ) was also measured.

At 90 per cent $T_{1}$ recovery, an identical dose of the same non-depolarizing relaxant administered intravenously if time permitted. Time from second dose to onset of maximum block (second dose Max) and 90 per cent $T_{1}$ recovery ( $\mathrm{REC} 90_{2}$ ) were then measured. At the conclusion of surgery, neuromuscular blockade was reversed with neostigmine $2.5 \mathrm{mg}$ and glycopyrrolate $0.5 \mathrm{mg}$. One way ANOVA was performed to determine significance between the groups. A paired $t$ test was performed between REC $90_{1}$ and REC $90_{2}$ for vecuronium and atracurium, respectively, in those patients who received two doses of the relaxants. A $\mathrm{p}<0.05$ was considered
TABLE I Variables in patient population

\begin{tabular}{lrll}
\hline & $\begin{array}{l}\text { Group I } \\
n=9\end{array}$ & $\begin{array}{l}\text { Group II } \\
n=I I\end{array}$ & $p^{*}$ \\
\hline Age & $42 \pm 8.42 \mathrm{yr}$ & $37.1 \pm 16.73 \mathrm{yr}$ & NS \\
Weight & $81.3 \pm 12.37 \mathrm{~kg}$ & $74.0 \pm 13.06 \mathrm{~kg}$ & NS \\
Dialysis & $1 \pm 0.43 \mathrm{hr}$ & $1.13 \pm 0.95 \mathrm{hr}$ & $\mathrm{NS}$ \\
\hline
\end{tabular}

*A p value of $<0.05$ was considered significant.

statistically significant. All values are expressed as mean \pm SD.

\section{Results}

The results of the study are summarized in Tables I, II and III. There were no significant differences between the two groups in age, weight or time from last dialysis. Preoperative serum $\mathrm{K}^{+}$ranged from $3.6 \mathrm{mEq} \cdot \mathrm{L}^{-1}$ to $5.2 \mathrm{mEq} \cdot \mathrm{L}^{-1}$. There was also no significant difference in time of onset of succinylcholine block or SDC REC 90. After the initial dose of atracurium or vecuronium there was no significant difference between the two drugs in onset of first dose Max block, Start $\operatorname{Rec}_{1}, \operatorname{REC} 25_{1}, 75_{1}$, $25-75_{1}, 90_{1}$ or maximum blockade percentage achieved with a single dose of NDP

One patient in Group I (ATR) and three patients in Group II (VEC) did not receive a second dose of relaxant due to time constraints. There was no significant difference in second dose Max between the eight patients in

TABLE II Train-of-four measurements after relaxant administration

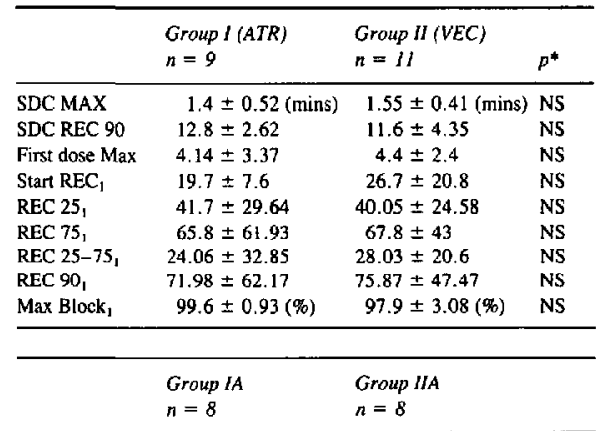

Second dose Max $2.52 \pm 1.17$ (mins) $2.37 \pm 0.69$ (mins) NS

\begin{tabular}{lllll} 
& & & \\
& $\begin{array}{l}\text { Group IB } \\
n=7\end{array}$ & $\begin{array}{l}\text { Group } I / B \\
n=5\end{array}$ & \\
\hline REC $90_{2}$ & $57.99 \pm 8.22$ (mins) & $89.23 \pm 25.97$ & $<0.05$ \\
\hline
\end{tabular}

*A p value $<0.05$ was considered significant. 
TABLE III Paired $\mathrm{t}$ test for atracurium and vecuronium

\begin{tabular}{lll}
\hline & Mean & $p^{*}$ \\
\hline Diff 90 ATR & $13.77 \pm 3.35$ mins & 0.0063 \\
Diff 90 VEC & $25.62 \pm 4.34$ mins & 0.0041 \\
\hline
\end{tabular}

* $p$ value less than 0.05 was considered significant.

each group who did receive a second dose of nondepolarizing relaxant (Group IA and Group IIA). In Group IA one patient did not reach 90 per cent $T 1$ return after the second dose of atracurium before the case was finished. The end of the case occurred 55.3 minutes after injection of the second dose (REC 90 77.34 mins). In Group IIA, three patients did not reach 90 per cent $T_{1}$ recovery before the end of the procedure. The times from injection of second dose of vecuronium to the end of the procedure in these patients were 75 minutes (REC $90_{1}$ 34.75 mins), 44 minutes (REC 90,77.3 mins) and 70 minutes (REC 90,76.3 mins).

The difference in REC $90_{2}$ between patients (Group IB) who achieved 90 per cent $T_{\text {I }}$ recovery after a second dose of atracurium (57.99 \pm 8.22 mins) and those (Group IIB) reaching 90 per cent $T_{1}$ recovery after a second dose of vecuronium ( $89.23 \pm 25.97$ mins) was statistically significant. A paired $t$ test comparing REC $9 \mathrm{O}_{2}$ with REC 90 (Diff 90) for patients in Group IB and IIB revealed that REC $90_{2}$ was significantly longer for each group (Table III). However, examination of the data reveals Diff 90 for patients in IIB (vecuronium) was much longer (25.62 \pm 4.34 mins) than in IB (atracurium $13.77 \pm 3.35$ mins).

\section{Discussion}

Hunter et al ${ }^{8}$ administered $0.5 \mathrm{mg} \cdot \mathrm{kg}^{-1}$ boluses of atracurium to normal and anephric surgical patients and found time to beginning of neuromuscular blockade and maximum suppression longer in anephric than normal patients while duration of block was the same. When $0.2 \mathrm{mg} \cdot \mathrm{kg}^{-1}$ increments were given, no evidence of accumulation was found in the normal or anephric patients. Another study ${ }^{3}$ found no evidence of accumulation in renal failure patients receiving atracurium, while deBros et $a l{ }^{4}$ showed no difference in pharmacokinetic or pharmacodynamic parameters between normal and anephric surgical patients receiving the drug. There seems to be ample evidence, then, that in terms of pharmacokinetics and pharmacodynamics atracurium is an appropriate muscle relaxant for use in the renal failure patient.

Vecuronium has also been described as a suitable non-depolarizing agent for the clinically or anatomically anephric patient. ${ }^{1,2}$ Fahey $e t a l .{ }^{2}$ showed no difference in onset or recovery time of vecuronium between normal and cadaver transplant patients. Another group ${ }^{1}$ found no difference in duration of block or evidence of accumulation after multiple doses of vecuronium were administered to normal and anephric patients. However, Lynam et al. ${ }^{5}$ while finding no difference in onset time or time from injection to beginning of recovery, did demonstrate an increase in duration from injection to 25 per cent recovery and recovery time ( $25-75$ per cent recovery) in cadaver transplant patients when compared with normal renal function patients receiving the same bolus dose $\left(0.1 \mathrm{mg} \cdot \mathrm{kg}^{-1}\right)$ of vecuronium. Bencini ${ }^{9}$ found a slower onset time of vecuronium in renal patients receiving $100 \mu \mathrm{g} \cdot \mathrm{kg}^{-1}$ of vecuronium compared to normal patients.

Bevan $^{6}$ studied what effect the administration of multiple top-up doses of $10 \mu \mathrm{g} \cdot \mathrm{kg}^{-1}$ of vecuronium at 10 per cent recovery of $T_{1}$ might have when administered to renal failure and normal renal function patients. Renal failure patients who received more than 10 top-up doses (generally constituting a period of two hours) showed a progressive, significant increase in the duration of action of approximately 50 per cent over two hours. This evidence of accumulation was not seen in patients with normal renal function. Our study does not compare the effects of vecuronium in renal transplant patients with normal patients. However, we did contrast the effects with that of atracurium, a drug well documented to be pharmacokinetically unaffected in the renal transplant patient. . $^{3,8}$

While we found no significant difference in any measured parameter between the two groups after a single dosage as Lynam $^{5}$ and Bencini ${ }^{9}$ did, we did find evidence of accumulation after a second dose of vecuronium when compared to the effect of a second dose of atracurium. This would seem to support Bevan's evidence of accumulation in the renal failure patient as a whole. The reason for this evidence and that of Lynam and Bencini's studies is unclear.

In Lynam's study, plasma clearance of vecuronium was measured. There was no correlation between the duration of blockade and plasma clearance of vecuronium in the renal failure patient.

Fisher et al. ${ }^{10}$ demonstrated a cumulative effect when vecuronium was administered after initial doses varying from $30-80 \mu \mathrm{g} \cdot \mathrm{kg}^{-1}$. When five repeated doses of $20 \mu \mathrm{g} \cdot \mathrm{kg}^{-1}$ were administered at 25 per cent $T_{1}$, the component of plasma concentration resulting from the initial dose had entered the elimination phase. This was felt to explain the cumulation seen with repeated doses of vecuronium in patients with normal renal function.

Bencini ${ }^{9}$ measured urinary excretion of vecuronium in nornal patients and found only moderate amounts of 
vecuronium in the urine. In rats ${ }^{11}$ a maximum of 14 per cent of an injected dose of vecuronium is excreted unchanged in the urine. To determine what effect urine output might have on vecuronium clearance and accumulation in our study, we compared the REC $90_{2}$ value of these patients with "low flow" urine output $(n=3)$ after transplant insertion ( $86.89 \pm 36.2$ mins) with those $(\mathrm{n}=2)$ who had normal urine flow $(92.7 \pm 5.9$ mins). There was no statistical significance between the two values but the patient population was small.

One factor that might be considered is the use of isoflurane. Isoflurane is known to effect the duration of non-depolarizing muscle relaxants including the two agents used in our study. ${ }^{12-14}$ Rupp et al.$^{13}$ compared the $E D_{50}$ of atracurium when given to patients recejving balanced anaesthesia and patients receiving 0.75 per cent end-tidal isoflurane and found the $\mathrm{ED}_{50}$ to be significantly less in patients receiving isoflurane. Rupp ${ }^{13}$ also studied the effects of isoflurane on vecuronium and found that it interacts differently with vecuronium from other non-depolarizing muscle relaxants. While enflurane and isoflurane werc equipotent in augmentation of nondepolarizing blocks caused by d-tubocurarine or pancuronium, isoflurane was less potent than enflurane in augmenting vecuronium. Also, increasing the concentration of these inhalational agents had less effect on neuromuscular blockade produced by vecuronium than on blockades produced by pancuronium or $\mathrm{d}$-tubocurarine. In fact, there was no difference in onset or cessation of block with vecuronium when increasing end-tidal isoflurane concentration.

Rupp et $a l .^{14}$ calculated the $\mathrm{ED}_{50}$ of vecuronium at an end-tidal isoflurane concentration of 0.7 per cent to be $14.7 \mu \mathrm{g} \cdot \mathrm{kg}^{-1}$. Sokoll ${ }^{10}$ showed the ED $_{50}$ of atracurium to be $70 \mu \mathrm{g} \cdot \mathrm{kg}^{-1}$ using a $0.6-0.68$ per cent end-tidal isoflurane concentration. Another study ${ }_{12}$ demonstrated an $\mathrm{ED}_{50}$ of $68 \mu \mathrm{g} \cdot \mathrm{kg}^{-1}$ of atracurium in patients receiving 0.75 per cent end-tidal isoflurane. Our study used doses of $50 \mu \mathrm{g} \cdot \mathrm{kg}^{-1}$ of vecuronium and $250 \mu \mathrm{g} \cdot \mathrm{kg}^{-1}$ of atracurium. These doses represent 3.4 times the $\mathrm{ED}_{50}$ of vecuronium as shown in Rupp's ${ }^{14}$ study and 3.57 times the $\mathrm{ED}_{50}$ of atracurium as shown in Sokoll's ${ }^{12}$ and Rupp's ${ }^{13}$ work. Considering that isoflurane seems to potentiate vecuronium less than other non-depolarizing agents and that our study utilized a proportionately slightly higher dose of atracurium than vecuronium, we do not feel that the presence of isoflurane explains the accumulation effect of vecuronium when compared to atracurium in the renal transplant patient.

This conclusion is supported by Lepage et al. 's ${ }^{15}$ study of vecuronium and atracurium in patients with end stage renal failure. An accumulative effect was found with top-off doses of vecuronium when compared with supplemental doses of atracurium and no inhalational agent was used.

Gramstad and Gjerlow ${ }^{16}$ studied the interaction of cyclosporin and its solvent with atracurium and vecuronium in cats. After a stable 50 per cent blockade was achieved by a constant rate of infusion of the two drugs $0.8 \mathrm{mg} \cdot \mathrm{kg}^{-1}$ Sandimmune (cyclosporin in cremophor and ethanol) was injected intravenously over five minutes. Sandimmune potentiated the blockade induced by vecuronium from 50.7 per cent before injection to 95.2 per cent. The median blockade induced by atracurium increased from 51.3 per cent to 72.4 per cent. In another group of cats receiving an equal amount of solvent alone, containing cremophor, an agent known to decrease the onset time of pancuronium, a vecuronium analogue, the 50 per cent vecuronium blockade increased to 78 per cent, while the atracurium blockade was unaffected. Sandimmune alone was not found to have any affect on neuromuscular transmission.

Our patients all received $6 \mathrm{mg} \cdot \mathrm{kg}^{-1}$ oral Sandimmune (without cremophor) within six hours of surgery and did not receive any intravenously during the procedure. While the administration of intravenous Sandimmune during a renal transplant may be of clinical significance with regard to muscle relaxants, we do not believe it explains the apparent accumulation of vecuronium in our cadaver transplant recipients who only received oral Sandimmune.

All of our patients easily reversed at the end of the procedure with no evidence of reparalysis in either group. This is in agreement with Bevan et al., ${ }^{6}$ as is our conclusion that vecuronium may accumulate in the renal transplant patient. However, with proper neuromuscular monitoring, the drug can still be clinically useful and even beneficial in this patient population considering its marked absence of systemic and cardiovascular side effects.

\section{References}

1 Hunter JM, Jones RS, Utting JE. Comparison of vecuronium, atracurium and tubocurarine in normal patients and in patients with no renal function. Br $J$ Anaesth 1984; 56: 941-51.

2 Fahey MR, Morris RB, Miller RD, Nguyen $T-L$, Upton $R A$. Pharmacokinetics of Org NC45 (Norcuron) in patients with and without renal failure. Br J Anaesth $1981 ; 53$ : 1049-53.

3 Mongin-Long D, Chabrol B, Baude $C$ et al. Atracurium in patients with renal failure. Clinical trial of a neuromuscular blocker. Br J Anaesth 1986; 58: 44S-48S. 
4 deBros FM, Lai A, Scott $R$ et al. Pharmacokinctics and pharmacodynamics of atracurium during isoflurane anesthesia in normal and anephric patients. Anesth Analg $1986 ; 65 ; 743-6$

5 Lynam DP, Cronnelly $R$, Arden J, Castagnoli $K$, Canfell $C$, Miller $R D$. The pharmacodynamics and pharmacokinetics of vecuronium in putients with and without renal failure. Anesthesiology 1986; 65: A296.

6 Bevan DR, Donati $F$, Gyasi H, Williams A. Vecuronium in renal failure. Can Anaesth Soc J 1984; 31: 491-6.

7 Basta SJ, Savarese JJ, Ali HH, Moss J, Gionfriddo $M$ Histamine releasing potencies of atracurium, dimethyl tubocurarine and tubocurarine (Short Communication). Br J Anaesth 1983; 55: 105S-106S.

8 Hunter $J M$, Jones RS, Uting JE. Use of atracurium in patients with no renal function. Br J Anaesth 1982; 54: 1251-8.

9 Bencini AF, Scaf AH, Sohn $Y J$ el al. Disposition and urinary excretion of vecuronium bromide in anesthetized patients with normal renal function or renal failure. Anesth Analg 1986; 65: 245-51.

10 Fisher DM, Rosen JI. A pharmacokinetic explanation for increasing recovery time following larger or repeated doses of nondepolarizing muscle relaxants. Anesthesiology 1986; 65: 286-91.

11 Upton RA, Ngwyen T-L, Miller RD, Castagnoli $N$. Renal and biliary elimination of vecuronium (ORG NC45) and pancuronium in rats. Anesth Analg 1982; 61: 313.

12 Sokoll MD, Gergis $S D$, Mehta $M$, Ali $N M$, Lineberry $C$. Safety and efficacy of atracurium (BW33A) in surgi$\mathrm{Cal}$ patients receiving balanced or isoflurane anesthesia. Anesthesiology 1984; 58: 450-5.

13 Rupp SM, Fahey MR, Miller RD. Neuromuscular and cardiovascular effects of atracurium during nitrous oxide - fentanyl and nitrous oxide - isoflurane anesthesia. Br J Anaesth 1983; 55: 67S-70S.

14 Rupp SM, Miller RD, Gencarelli PJ. Vecuroniuminduced neuromuscular blockade during enflurane, isoflurane and halothane anesthesia in humans. Anesthesiology 1983; 60: 102-5

15 Lepage $Y Y$, Malinge $M$, Cozian A, Pinaud $M$, Blanloeil $Y$, Souron $R$. Vecuronium and atracurium in patients with end-stage renal failure. A comparative study. Вг J Anaesth 1987; 59: 1004-10.

16 Gramstad L, Gjerlow JA, Hysing ES, Rugstad HE. Interaction of cyclosporin and its solvent, cremophor, with atracurium and vecuronium. Studies in the cat. Br J Anacsth 1986; 58: 1149-55.
Résumé

Vingt patients classe ASA III devant subir une transplantation rénale cadavérique ont été étudiés. Après une récupération à 90 pour cent de l'ondée-de-quatre après administration de $1.0 \mathrm{mg} \cdot \mathrm{kg}^{-1}$ de succinylcholine afin de faciliter l'intubation trachéale, neuf patients ont reçu de l' atracurium $0.25 \mathrm{mg} \cdot \mathrm{kg}^{-1}$ (Groupe 1) et ll patients ont reçu du vécuronium $0.05 \mathrm{mg} \cdot \mathrm{kg}^{-1}$ (Groupe II) par voie intraveineuse. Les mesures suivanes ont été faites: le temps d'installation maximal du bloc (Ist Dose Max), début d' injection jusqu' au débus de la récupération (Start $\left.R E C_{l}\right)$, début d' injection à 25 pour cent de $T_{I}$ de la récupération du twitch (REC 251), de l'injection à 75 pour cent $T,(R E C 75$ )), de l'injection à 90 pour cent $T_{1}\left(R E C 90_{1}\right)$ et le temps de $25-75$ pour cent de la récupération de $T_{l}$ (REC 25-75,). Le bloc maximal (Max block ${ }_{1}$ ) a aussi été mesuré. A 90 pour cent de la récupération de $T_{i}$, si le temps l' a permis, une dose identique du relaxant approprié fut administrée. Le temps de la deuxième dose à l'installation du bloc maximum (2nd dose Max) et 90 pour cent de la récupération après la deuxième dose $\left(R E C \mathrm{SO}_{2}\right)$ ont été mesurés. A la fin de la chirurgie, le bloc neuromusculaire a été antagonisé avec de la néostigmine $2.5 \mathrm{mg}$ et du glycopyrrolate $0.5 \mathrm{mg}$. L'érude ANOVA a été faite afin de déterminer la significativité de la performance entre les groupes et un $p<$ 0.05 a été considéré significatif. Un test de t-pairé a aussi été fait entre $\mathrm{REC} 9 \mathrm{O}_{1}$ et $\mathrm{REC} 9 \mathrm{O}_{2}$ poucr l'atracurium et le vécuronium respectivement. Un p $<0.05$ a aussi été considéré significatif. Les mesures de la première dose Max, Start REC, REC $25_{1}$, REC 75, REC $90_{1}$, REC 25-75, et Mar block n' $^{\prime}$ ont pas révélé de difference significative entre les patients ayant reçu une dose initiale d' atracurium et ceux qui ont reçu du vécuronium. Chez les patients ayant réçu une deuxième dose de relaxant, il $n^{\prime} y$ avait aucune différence dans le temps d'installation du bloc maximal (2nd dose Max). Cependant, le temps de récupération d 90 pour cent $\left(\operatorname{Rec} 90_{2}\right)$ après une deuxième dose de vécuronium $(89.23 \pm 25.97$ mins) était significativement plus long que celui après une deuxième dose d'atracuriun (57.99 \pm 8.22 mins) chez Les patients ayant récupéré à 90 pour cent avant la fin de la procédure chirurgicale. Aussi une comparaison de $R E C \mathrm{SO}_{2}$ et REC 90, (Diff 90) pour l'atracurium et le vécuronium, respectivement, a démontré que le REC $9 \mathrm{O}_{2}$ est significativement plus long pour chaque groupe de patients ayant reçu deux doses de relaxant. Cependant, l'étude des données a démontré que la Diff 90 du vécuronium (25.62 \pm 4.34 mins) étant plus longue que celle de l'atracurium (13.77 \pm 3.35 mins) même si des doses équipotentes de ces médicaments ont été administrées. Ainsi, il y avait une évidence que le vécuronium pourrail s'accumuler chez les patients ayant subi une greffe rénale cadavérique. 